BULLETIN (New Series) OF THE

AMERICAN MATHEMATICAL SOCIETY

Volume 43, Number 1, Pages 89-91

S 0273-0979(05)01096-7

Article electronically published on November 22, 2005

\title{
ABOUT THE COVER: ON THE DISTRIBUTION OF PRIMES-GAUSS' TABLES
}

\author{
YURI TSCHINKEL
}

In 1791, Carl Wilhelm Ferdinand, the Duke of Brunswick, gave fourteen-yearold Gauss a collection of mathematics books which included logarithm tables by Schulze 11 These were the first logarithm tables that Gauss possessed. The tables listed decimal logarithms up to 7 digits as well as natural logarithms of all natural numbers up to 2200 and prime numbers up to 10,009 [3]. Gauss worked on extending the tables: a computation of $\ln (10037)$ can be found in his papers from that time.

It is conceivable that seeing and using the tables of logarithms of primes, Gauss was led to discover the law governing the distribution of primes, the Prime Number Theorem. Throughout his life Gauss returned again and again to this issue, matching data from published tables of prime numbers with his prediction.

Here are the first lines of a four-page letter from Gauss to his student Johann Franz Encke, lieutenant of artillery and later astronomer in Berlin, dated December 24,18492

My distinguished friend,

Your remarks concerning the frequency of primes were of interest to me in more ways than one. You have reminded me of my own endeavors in this field which began in the very distant past, in 1792 or 1793, after I had acquired the Lambert supplements to the logarithmic tables. Even before I had begun my more detailed investigations into higher arithmetic, one of my first projects was to turn my attention to the decreasing frequency of primes, to which end I counted the primes in several chiliads and recorded the results on the attached white pages. I soon recognized that behind all of its fluctuations, this frequency is on the average inversely proportional to the logarithm, so that the number of primes below a given bound $n$ is approximately equal to

$$
\int \frac{d n}{\log (n)}
$$

where the logarithm is understood to be hyperbolic. Later on, when I became acquainted with the list in Vega's tables (1796) going up to 400031, I extended my computation further, confirming that estimate. In 1811, the appearance of Chernau's cribrum gave me much pleasure and I have frequently (since I lack the patience for a continuous count) spent an idle quarter of an hour to count another chiliad here and there; although I eventually gave it up without quite getting through a million. Only some time later did I make use of the diligence of Goldschmidt to fill some of the remaining gaps in the first million and to continue the computation

Received by the editors August 15, 2005.

${ }^{1}$ The cover page of this book is at www.math.princeton.edu/ $y$ tschink/.gauss/tafel2.pdf.

${ }^{2}$ The scan of the original is at www.math.princeton.edu/ ytschink/.gauss/Briefe-B.pdf. This translation is from Appendix B to 2 . 
according to Burkhardt's tables. Thus (for many years now) the first three million have been counted and checked against the integral. A small excerpt follows: ....

The continuation of the letter (p. 2) is reproduced on the cover of this issue of the Bulletin. The scan on p. 14 of [1] shows one of Gauss' tables summarizing information about the distribution of primes between 1.9 and 2 million. There are slight discrepancies with actual numbers. For example, there are 896 primes between 1910000 and 1920000 and not 897 as in the table. The correct total number is 6904 and not 6902 . We have

$$
\int_{1900000}^{2000000} \frac{\mathrm{d} x}{\ln (x)}=6904.54423628 \ldots
$$

Gauss computed 6904.54424 ; the scan on p. 29 of [1] shows his computation of $\operatorname{Li}(x)$, for $x=10^{5}, \ldots, 2 \cdot 10^{6}$, in steps of 100,000 . The table on p. 20 of [1] shows numbers of primes in intervals between 2000000 and 3000000; the actual number of primes is 67883 and not 67862 .

Clearly, questions about the distribution of primes were much more than of "idle" interest for Gauss - he had a multitude of obligations 3 It is perhaps worth noticing that Gauss never plotted the graph of the function $\pi(x)$ or $\operatorname{Li}(x)$, the way one would introduce the problem nowadays [4].

\section{ACKNOWLEDGMENTS}

The scans are courtesy of the Niedersächsische Staats- und Universitätsbibliothek, Göttingen. I thank Dr. S. Wiedmann for his help and Prof. B. Mazur for advice and comments.

\section{REFERENCES}

[1] C. F. Gauss, Tables, http://www.math.princeton.edu/ ^ytschink/.gauss/Gauss-NachlassMath-18.pdf.

[2] L. J. Goldstein, A history of the prime number theorem, Amer. Math. Monthly 80 (1973), 599-615. MR0313171 (47:1726)

[3] F. Klein, Materialien für eine wissenschaftliche Biographie von Gauss, Leipzig, Teubner Verl. (1911).

[4] D. Zagier, The first 50000000 prime numbers, Math. Intelligencer 0 (1977), 7-19. MR0643810 (83e:10003)

Mathematisches Institut, Bunsenstr. 3-5, 37073 Göttingen, Germany; and Courant Institute of Mathematical Sciences, 251 Mercer Street, New York, New York 10012

E-mail address: yuri@uni-math.gwdg.de

\footnotetext{
${ }^{3}$ From a letter to Dirichlet, September 9, 1826: "I wish you from my heart a situation in which you can, as much as possible, remain the master of your time and choice of your tasks."
} 


\begin{tabular}{|c|c|c|c|c|}
\hline Unter & $\begin{array}{l}\text { gibtes } \\
\text { Prinjablim }\end{array}$ & $\int_{\frac{d n}{4-y n}}^{\text {gntegral }}$ Siffer & $\begin{array}{l}\text { Hore } \\
\text { Formel }\end{array}$ & Aburich. \\
\hline 500000 & 41556 & $41606,4+50,4$ & 41596.9 & $+40,9$ \\
\hline 1000000 & 78501 & $78627,5+126,5$ & 78672,7 & $+171, y$ \\
\hline 500000 & 174112 & $114263.1+151,1$ & 114374,0 & $+264,0$ \\
\hline 2000000 & 148883 & $149054.8+171.8$ & 149233.0 & +350.0 \\
\hline 2500000 & 183016 & $1 8 \longdiv { 3 2 4 5 , 0 } + 2 2 9 . 0$ & 1834951 & +47 \\
\hline 3000000 & 216745 & $216970.6+225.6$ & 217308,5 & +563.0 \\
\hline
\end{tabular}

Dass Legendre sich cunht mit dieserm Gegenstande besthif. tigt hat, war mir nuht bekannt; aut Nerainlassung Thres Mrefes habe ith in seiner Theorie des Nombres nachyesehew. und in dar zweiten Carsgabe einge darant berighliche Seiter. gefunder, die ich fricher ülersehen (odes seildem verges. gen) haben mufs. Legendre gebranchs die Formel

$$
\frac{n}{\log n-A}
$$

200 A eine Constante dein SOll, fier welche or 1,08366

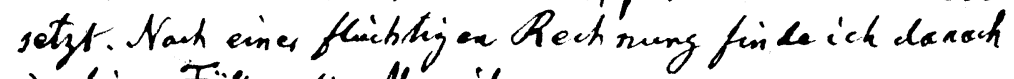
in dijen Fïllen die Atbweich aryen

$$
\begin{aligned}
& -23.3 \\
& +42.2 \\
& +68.1 \\
& +92.8 \\
& +159.1 \\
& +167.6
\end{aligned}
$$

Diesc Defferemen sind woch Kleiner als che muth dem Interral, sie scheinen aber bei gunshmeniem $n$ stot r himaller no wachsen als die se, ivo dafs leicht mig láh ware, dofy bei viel weiterer Fortsetrung jene die lettern über.

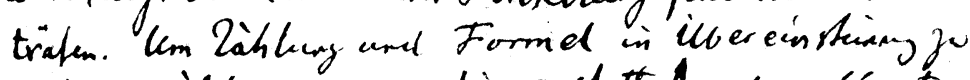
inigen mifiteman respective anstatt $A=1,08366 \mathrm{setzen}$

1.07682

1,07582

1,07529

1,07179

1,07297 